\title{
Globalization of the labour market - Circular migration in Hungary
}

\author{
Imola Cseh Papp \\ Faculty of Economics and Social Sciences, \\ University of Szent István, \\ Hungary \\ papp.imola@gtk.szie.bu
}

\section{Svitlana Bilan}

Faculty of Management, Rzeszow University of Technology

Poland,

s.bilan@prz.edu.pl

\section{Krisztina Dajnoki}

Faculty of Economics and Business, University of Debrecen

Hungary

dajnoki.krisztina@econ.unideb.hu

Abstract. Explanation of the recently intensified willingness to migrate has many components, among which migration for the purpose of employment is a paramount one. The study deals with the exploration of the three basic characteristics of globalizing employment in Central and Eastern Europe and Hungary in particular: migration motivations of foreign employees, their labour market characteristics and the degree of their social integration. The authors aim to provide a comprehensive picture of the content of engagement - which is continuously becoming significant in practice - of highly qualified employees originating from developed countries. The findings at the end of the analysis due to the size and homogenous nature of the sample - are mostly thoughtexperiments, but we expect to provide a valid contribution to scientific and everyday discussions about migration.

Keywords: integration, labour market, migrants, Hungary.

JEL Classification: J21, J6, O15, R23. 


\section{INTRODUCTION}

With the significant increase of labour mobility, globalization of labour market - following the same processes at the commodity market and financial market - became more and more characteristic during the last decade. The process, on the one hand, materialized in the physical movement of workforce in the course of which a portion of skilled workforce transferred from the Central and Eastern European region to more advanced economies; on the other hand, as a consequence of digitalization, the number of employees who carry out their work online is constantly rising. Quality of work-related living space is an important competitive factor, in which the starting position of Budapest is particularly encouraging. Hungary is an open economy, so identification of trends in globalization and mapping the challenges and opportunities that arise from it might become one of the keys to future competitiveness.

Hungary is not exposed to a significant migration impact, but it became a target country for foreign workers in the 1990s, neighbouring countries especially. During the decades since then, interesting economic changes have taken place, especially in the field of foreign employment legalization: multiple countries have opened their labour markets for foreign employees and this has contributed to easier and more self-explanatory border crossing for the people migrating abroad. Management of employmentrelated migration is an economic, social and political challenge for the EU Member States, including Hungary. Labour market integration is a starting point and a precondition for social integration of immigrants. The situation of Hungary is special, since in the past decades, most of its immigrants were the Hungarians living beyond the country's borders, for them labour migration has become a favourable opportunity for integration. By now, the situation has changed; cultural diversity in Hungary and the multilateral nature of Hungarian labour market are characterized by the fact that foreign employees are the citizens of a high number of nations and countries of origin.

\section{LITERATURE REVIEW}

\subsection{Definitions}

The particularly increased international migration of the second half of the $20^{\text {th }}$ century, which was a result of the suddenly occurring demographic boom, was a great challenge for decision-makers (Sík, 2012). This is a trend, the specifics of which change depending on global macro factors on the one hand and on the other hand on socio-cultural characteristics of countries and regions. There are many variations of the research and conceptual approaches of migration, but experts agree that its focus is on human migration. By present day, the centre of interpretation of migration is shifting from population movement to individual actions ${ }^{1}$. Present paper highlights only a few important correlations from the available rich technical literature without being exhaustive.

Movements across country borders are called international migration by conventional technical literature, however in the current terminology of the European Union movements crossing the boundaries of integration are also referred to as migration.

Circular migration means the back and forth movements between certain countries. Within the unified labour market of the European Union, this type of migration is a phenomenon that keeps

\footnotetext{
${ }^{1}$ Endre SIK is one of the most important researchers of the topic in Hungary, who realized long before his colleagues that migration would be one of the most significant challenges of the future for modern societies at the same time the primary source of new societal conflicts.
} 
becoming more and more frequent. One of the new forms of circular migration is business migration, which is participated by the executives, the management, and the skilled experts of foreign investors and multinational corporations.

From a statistical point of view, migration is a one-time event. Circulation is a migration system consisting of at least three interconnected elements, in which multiple recurrent movements of individuals take place (Illés - Kincses, 2009). Currently, the following types are of particular interest within international migration-related technical literature: brain circulation, short-term (temporary, seasonal) labour circulation and education-aimed circulation (high school and university students).

Fleischer (2017) points out the long lasting, but not necessarily permanent nature of migration when he compares the displacement of individuals to the seasonal migration of migratory birds. Currently, 244 million people (3.3\% of the total population today) live in a country different to where they have born due to the particularly intensified (or forced) intentions for migration (Fleischer, 2017).

\subsection{Characteristics}

Intensification of labour migration within the Eastern European region is in accordance with the global trends that characterize the age of globalization (Dajnoki - Héder, 2017; Simionescu et al., 2017b; Streimikiene et al., 2016; Rausser et al., 2018; Bilan et al., 2017). Cross-border economic / social / cultural processes and international regulations stimulate and promote the intention of people to seek jobs far from their homeland, where they find better conditions, according to their own judgment, imaginations, plans and possibilities (Bodó, 2016). Transnational migration affects at least two independent countries. According to the current interpretation, migrants are not permanently separated from the origin country, but they are attached to the host country through their work, accommodation and their other activities (Illés - Kincses, 2009).

The study of Bodo (2016) approaches the topic of migration from the aspect of people crossing the border; it confirms the fact that factors hindering migration and the crossing of borders have loosened during the last decades. Traveling time became shorter, physical distances can be overcome more easily, and the financial burden of travelling has been significantly reduced as well. The easy bridging of distances does not strengthen the feeling of separation, so immigrants leave their original environment knowing that they can return at any time, they do not have to face the persistence of homelessness. Communication tools are available to everyone, and the ability to make contact at any time eases the feeling of separation as well. Over the past two and a half decades, there have been many releases in terms of the penetrability of borders. This allowed foreign employees to simplify their migration practices and experience migration as a form of common activity. Multiple countries have opened up their labour markets for foreign employees, and this has mostly terminated illegal "black labour"

As a consequence of the above changes, transnational theories have strengthened. Accordingly, migrants who stay in a distant physical-social-cultural space far from their home for a long time (or they switch their location multiple times between two or more spaces), will be able to develop a bond to both places simultaneously, at the same time (Lados - Hegedus, 2012).

\subsection{Assimilation and integration}

Migration initiates many professional debates, but experts agree that the social and economic integration of migrants is indispensable. The earliest theoretical approach to the concept of integration is the assimilation model elaborated by Park (1928). According to the model, assimilation of immigrants (ethnic minorities) into majority society is a linear and irreversible process. The receiving society is 
characterized by a dominant majority culture, which immigrants will sooner or later assimilate into, by abandoning their language and cultural customs. Gordon (1964) realized that the assimilation process consists of different phases, and besides cultural assimilation (acceptance of the cultural patterns of the receiving society), he also distinguished structural assimilation (integration into the institutions and social structures of the receiving society), and identification assimilation (identification with the majority society).

With the spread of the ideas of cultural and ethnic pluralism ${ }^{2}$, the place of the assimilation model was taken over by integration models that consider various possible outcomes of the integration process. It was realized that economic, social and ethnic stratification and cultural diversity of the receiving society enabled different integration patterns. While assimilation postulates the one-way adaptation of immigrants, integration is culturally a two-directional process in the course of which immigrants become members of the receiving society, that in the meantime they also form its own cultural composition while preserving their own ethnic, cultural identity.

Integration of immigrants means the establishment of multilateral relationships between immigrants and majority society, the success or failure of which depends on the openness and the level of prejudice of the receiving society as well (Bijl et al., 2008).

Analysis of the integration of immigrants can be studied in different dimensions, from general to interpersonal:

- Cognitive (cultural) integration: it means the learning of language, norms, behaviour, habits. Cultural integration can be based on appropriate communication between migrants and the receiving society, including information exchange and assistance.

- Structural integration: it refers to the legal, economic, institutional level integration of individuals, from the aspect of income, living standards, education, labour and labour safety, minority rights and accommodation. Structural integration can be achieved through learning and socialization processes.

- Social integration: development of networks of contacts with fellow immigrants, local residents, relatives, friends, colleagues, neighbours and the accumulation of social capital.

- Emotional (identification) integration: it refers to the development of the feeling of belonging to an ethnic group or a receiving society, which is a stable basis for many forms of integration.

Political concept of integration according to the European Union (European Commission 2003) is a two-way process based on mutual rights and obligations, which provides full participation for the immigrant. Opposite of the integration of migrants is segregation and social exclusion. The economic, social structures and ethnic hierarchies of the receiving society limit the access of different groups to different resources (job opportunities, accommodation, education) (Barth - Noel 1972; Kovách et al., 2015; Simionescu et al., 2017a; Balcerzak, 2016).

The social capital theory is of paramount significance in terms of social integration and the explanation of the functioning of social networks. Social integration can be realized in two ways: first, based on similar values, in which case the necessary social cohesion is created through value similarity; on the other hand, on the basis of interest originating from the relations of power - economy - division of labour; in this case cohesion is provided by identical interests (Utasi, 2002). According to the approach of Stone and Hughes (2002), social networks can be informal (based on family, friendship and neighbourly relations) and formal (group-based relationships and voluntary companies and institutions). For immigrants, informal networks are more significant; however, their integration is also facilitated by formal organizations. Formalization and expansion of informal networks would be an important social interest,

${ }^{2}$ Multicultural society does not seek the assimilation of minorities or immigrants. 
along with the strengthening of existing formal networks. However, presence of their own ethnic community in the receiving country offers integration opportunities for immigrants, which are independent from the majority society in terms of both labour market and social/cultural aspects.

Analysing the settling patterns of immigrants, the study of Portes and Böröcz (1989) also confirms that the circumstances of leaving their home country and the original class status of immigrants as well as their receptiveness of the receiving country result in very different patterns of integration. Interaction between individual characteristics and structural factors has a particularly significant role (Zhou, 1997). The "success" of integration for immigrants also depends on which segment of society and labour market they are integrating into (Portes - Böröcz, 1989). Based on Oláh et al. (2017), young people who worked in parallel with or before their studies are more concerned about that the migrants seize their jobs than those who have not worked previously. The analysis of Horn and Konya (2016) on international data concerning cultural and economic assimilation, confirms - based on data from 16 countries - the conclusion that linguistic assimilation is an important indicator of the success of immigrants within the labour market.

The study of Gödri (2016) attempted to provide a comprehensive picture of the integration of immigrants in Hungary based on the Zaragoza indicators. In terms of the primary field of integration the labour market - he reveals the explanatory factors of the main indexes. According to this, immigrants arriving to and living in Hungary are younger, more educated and have better position within the labour market than the domestic population. The higher employment rate of the population in Hungary with foreign nationality or foreign origin is an exception among EU countries. Its explanation primarily lies in the characteristics of immigrants. Besides the socio-demographic composition and settlement location of immigrants, the time of arrival to Hungary and citizenship, nationality and Hungarian language skills also determine the chances of labour market integration. With the increase of time spent in the receiving country, with the acquisition of Hungarian citizenship, in the case of Hungarian nationality and mother tongue, as well as learning the Hungarian language, labour market indexes mostly improve. All of these factors, however, mainly increase the employment opportunities of women, and their impact is weaker or ineffective for men.

Successful socio-economic integration is relevant if the indexes of immigrants on various fields labour market, education, accommodation circumstances, etc. - are not worse than that of the receiving society. Integration of immigrants into the receiving society can be interpreted as a complex, multidimensional process in the course of which immigrants become integrated into the economic, social and political structures of the receiving country and adapt to its cultural system, values and standards (Entzinger - Biezeveld, 2003).

\subsection{Economic effects}

Analysis of the short and long-term effects of this phenomenon is an important task. The influence of migration on economic and social life on the one hand is that it changes demographic characteristics, the size, structure and productivity of workforce and, on the other hand, it modifies the relationship between employees and employers.

There are several misconceptions about migration and immigration in public knowledge (Fleischer, 2017). One of them is that immigrants displace domestic labour and hence cause unemployment. According to another false assumption is that migrants are able to make up for Hungarian emigrants, although it is not typical for a catching up country to be both an origin and receiving country for migration at the same time. The general trend is that countries that are left by many people are also not 
attractive to immigrants and that very few citizens emigrate from countries that are attractive for immigrants.

In general, the influence of immigration on the labour market highly depends on the skills of migrants, the professional knowledge and abilities of existing employees, and the economic characteristics of the receiving country. The effects of immigration therefore always apply to a given time and place (Ruhs, Vargas-Silva, 2014; Simionescu et al., 2016).

The work of Bördős, Csillag and Orosz (2016) provides an observation-based insight into the current impact of immigrants on the employment and wage levels of the receiving country. The short-term influence of immigration on the labour market situation of domestic employees is very low. The affected groups and the extent of the impact depends on the level of professional and linguistic knowledge of immigrants. Immigration has a neutral or positive impact on the labour market situation of domestic employees in the medium term. This is due to two processes: On the one hand, companies adapt to the increase of labour supply resulting from immigration and switch to cheaper technologies that require lower qualifications. On the other hand, the relative value of additional jobs completing simpler activities carried out by immigrants is increasing and domestic workers occupy them.

\subsection{Characteristics of migrants arriving to Hungary}

Public opinion is considerably less concerned with the number of foreigners living in our country and their proportion in the labour market than the presence of Hungarians abroad. The reason for this is that foreigners are not a significant sized population, which consequently does not threaten the interests of domestic employees.

Hungarian legal system classifies those coming to Hungary into two categories: one is the citizens of the European Economic Area (i.e. the Member States of the European Union, Norway, Iceland, Liechtenstein and Switzerland) the other is the citizens of third countries. Members of the former group are able to work in Hungary without permission as of $1^{\text {st }}$ January 2009 (this means that a work permit is not required for them; however, they have a duty of registration). Citizens of third countries, which do not have the right to move and reside freely, can only work in Hungary with a permit.

International manufacturing companies based in Hungary, such as IBM or TATA gladly employ foreign labour. Their employees with higher education qualification usually tackle the task because of higher salaries. At the same time, they acquire knowledge that might give them additional benefits in their later career. It also frequently occurs that foreign employees come to Hungary as managers of a multinational company. In most cases, they come with their families, with a fixed-term contract.

The labour centre issues a work permit for the employment of a foreign person once if the employer has announced its claim in advance. The condition of granting the permit is that the foreign citizen entering Hungary shall meet the conditions of employment.

The number of foreigners working in Hungary shows an upward tendency: currently approximately 43,000 foreign employees work in Hungary. In 2016 a total of 6,303 work permits were issued by the Government Offices, which represents an increase of $20.2 \%$ as compared to the previous year. The influx of workers from neighbouring countries, mostly Serbia and Ukraine had a significant role in this increase. For them, Hungary is attractive due to better working conditions and in many cases, it is a temporary solution for them while they seek employment in other countries situated west of Hungary. The next large and globally outstanding number of employees come from China. There was a significant increase in the intention to work of Chinese people, as the number of licenses issued to them increased from 478 to 682 . 
Most work permits were issued in the capital during this year as well. At regional level, more than $60 \%$ of foreign employees who need a permit to become employed were concentrated in the Central Hungarian region.

In terms of the involved sectors of national economy, manufacturing industry remains the most popular for potential employees. $27.7 \%$ of the permits were issued in this area, but the sector of information and communication (14.6\%) as well as trade and repair $(10.3 \%)$ were also preferred.

There was a significant increase in terms of the number of employees working in jobs, which do not require technical qualification: jobs in office and business administration, and positions like machinery operator, mechanic and driver.

In 2016, a total of 6,303 work permits were issued and there were 7,283 valid work permits and 6 Blue Cards. This means that a total of 13,592 foreign employees worked in Hungary at the end of last year. This is 7.7\% more than at the end of 2015, when 12,617 foreigners worked here (Putnoki, 2016).

\section{METHODOLOGY}

\subsection{Preliminaries}

Besides the numerous international studies on the integration of migrants, there were multiple examinations dealing with this topic in Hungary recently as well.

According to previous research results, immigrants living in Hungary have a younger age structure as compared to Hungarian society; they are highly educated, and their economic activity is also higher than that of the Hungarian society (Illés - Kincses, 2009; Hárs, 2010; Lazányi et al., 2017; Danaj et al., 2018).

It is also verifiable that there is a significant number of unqualified employees with contracts, but the number of well-qualified so-called temporary skilled migrants is higher (Melegh et al., 2010) have emerged. The territorial situation and concentration of migrants is most characteristic in Budapest and its neighbourhood, and the growing involvement of women in international migration processes is also detectable (Biztos út ..., 2009; Örkény - Székelyi, 2010; Juhász et al., 2011). According to the research of Örkény and Székelyi (2010), immigrant groups have a large number of contact networks. However, 40$60 \%$ of these networks of contacts consist of family members and relatives, and most of the friends of immigrants are members of their own ethnic group, they very rarely associate with Hungarians (with the exception of Hungarians outside the border). Gödri (2010) found similar results in the scope of the analysis of immigrants coming from neighbouring countries, emphasizing the network-based establishment of migration.

The labour market integration of immigrants in Hungary is examined by Gödri (2017) along the Zaragoza indicators. An important statement of his study is that the higher employment rate of immigrants living in Hungary is mainly due to their composition and geographical location, but there are significant differences in terms of the country of origin and time of arrival; differences in terms of chances between genders are also detectable.

The novelty of present research is that it places the problem of migration into the context of employment.

\subsection{Circumstances of the analysis}

The aim of the research was to become acquainted with the social participation and integration of foreign workers arriving from different countries to Hungary. The study is primarily of exploratory nature (it highlights some causes and effects) and focuses on the following issues: 
- What inclined foreigners living in Hungary to leave their homeland and from which country they came from,

- Why, for what purpose, did they choose Hungary as a destination,

- Since when do they live in Hungary and for how long do they plan to stay,

- What is the composition of the group of employees arriving to Hungary in terms of sociodemographic characteristics and cultural/social resources,

- Are there differences among the different groups in terms of origin countries,

- What are the characteristics of the labour market,

- How are they integrated into society

The survey was conducted in 2017 in Hungary, by means of questionnaire method in Hungarian and English languages and it was preceded by a test survey. The sample $(n=314)$ of the study was based on individuals from different countries coming to Hungary in possession of a work permit. The sample was produced through personal relationships, complemented by the snowball method, which represents foreign workers working in Hungary by a gender-based distribution. It is important to point out that the sample presented in the study does not involve residents of camps that have already received or are still waiting for a refugee status and it does not cover illegally employed foreign citizens either; it only deals with legally employed individuals with work permits.

Based on the above, the following arise as research questions: what motivational factors affect foreign employment, and how can integration be interpreted within the scope of circular migration and transnationalism?

Exploration of the characteristics of the analysed sample was carried out by means of descriptive statistics, while the correlation between the country of origin of foreign workers and the examined quality variables was analysed by means of Chi-square test.

\section{EMPIRICAL RESULTS AND DISCUSSION}

\subsection{Demographic indexes and the duration of residence in Hungary}

Gender distribution of the 314 respondents participating in the study corresponds to the 2017 data published by the Central Statistical Office ${ }^{3}$ concerning foreign citizens residing in Hungary, according to which $44 \%$ of the respondents are women and $56 \%$ are men.

Age distribution of respondents is significantly closer to younger age groups, which is far from domestic employment rates ${ }^{4}$. Most foreign workers (55\%) belong to the age group between 25 and 34 years, $16 \%$ are under 25, 21\% are 35-44 years old and $8 \%$ are between 46 and 55 years old.

Composition of the marital status of participants shows an image, which is typical of current young age groups. Nearly half of the respondents (47\%) are single, one third live in a relationship, 12\% are married, $7 \%$ are engaged and $1 \%$ are divorced. Foreign employment was presumably facilitated if the individual was not in a committed relationship at the time of making the decision to emigrate. Those who live in marriage all have children.

Respondents are characterized by high qualification: $89 \%$ of foreign workers have graduated from a college or university, others from a high/secondary school.

\footnotetext{
${ }^{3}$ http://statinfo.ksh.hu/Statinfo/haDetails.jsp?query=kshquery\&lang=hu

${ }^{4}$ https://www.ksh.hu/docs/hun/xstadat/xstadat evkozi/e qlf058a.html
} 
Respondents represent a wide scale in terms of their home country. Most of them (22 people, $7 \%$ ) arrived to Hungary from India, followed by Italy and Germany, then as citizens of two neighbouring countries (Romania and Slovakia). Examining groups based on origin countries, distribution of foreign employees is as follows: EU member states: $39 \%$, neighbouring countries: $13 \%$, successor states of the Soviet Union: 13\%, Far East: 4\%, Middle East: 9\%, other Asian countries: 8\% the American continent: 9\%, Africa: 4\%, Australia - New Zealand: 1\%. Hungary's cultural diversity and the diversity of the Hungarian labour market are indicated by the fact that a total of 53 countries have replied to the questionnaire.

The mother tongue of $10 \%$ of foreign employees (31 people) is Hungarian, who are in almost the same proportion from Slovakia, Romania, EU member states, and from Serbia and Ukraine. Given the special situation that a significant proportion of those arriving in Hungary are Hungarians living beyond the borders, the neighbouring countries (Slovakia, Slovenia, Romania as EU member states, Ukraine as a successor state of the Soviet Union and Serbia) fall into the same category with the exception of Austria. Following Hungarian, the next are Arabic and English native speakers (8-8\%). 10\% of foreign employees (31 people) have Hungarian as mother tongue. Overall, 16\% of the sample (49 people) speak and understand the language of the country; an additional 7\% (22 people) are at medium level (according to their own opinion). They are either citizens of neighbouring countries, or they studied here or they are in a relationship with a Hungarian citizen. There is no detectable statistically significant difference among countries in terms of language skills.

One of the important measurement instruments of the integration of foreigners is the period they have already spent in the given country. The largest proportion $(43 \%)$ of the analysed sample is composed by employees who have been here for 1-3 years, while the smallest group (16\%) is represented by those who arrived more than 5 years ago. The others represent an equal proportion among the remaining categories: one-fifth of the sample work here for less than one year or for 3-5 years (20-21\%).

With regard to the planned duration of staying in Hungary, a small proportion $(6 \%)$ plan for only six months, while most of them (51\%) stay for $1-5$ years and a high proportion (36\%) plan beyond 5 years of stay. The proportion of uncertain respondents is $7 \%$, and nobody mentioned that they would stay here permanently.

Three quarters of high-skilled people plan for the long term in terms of their stay in Hungary. Time and length of the period spent in Hungary is the longest for individuals who are either Hungarian native speakers, or have studied here earlier, or who arrived with the purpose of reuniting their families. Analysing the sample by country of origin, major and statistically significant differences occur in one case in terms of the duration of migration: employees from outside the EU typically plan to stay in Hungary for multiple years.

For the analysis of the correlation between the country of origin of foreign employees and the quality of the examined variables, Chi-square test was applied. In summary, it was found that respondents do not show significant differences along different socio-demographic variables according to the analysis by country of origin. Foreign employees participating in the survey represent a nearly equal gender distribution, they are essentially single or live in a loose relationship in the capital, they are young, university or college graduates, and plan a 1-5 years of residence in Hungary.

\subsection{Migration objectives and information}

The model based on the push and pull effect is less typical of the current migration situation, therefore revealing the objective and motivation of working abroad is unavoidable in the scope of research activities involving the integration of immigrants. Development of motivations might be majorly 
affected by the previous supply of immigrants by societal and material resources and the political and economic situation of their home country. Foreign employment induced for different reasons may produce diverse integration patterns in the receiving country.

When asked about the reasons for foreign employment, and specifically the motivations behind selecting this particular country, responses pointed out that most foreigners $(38 \%)$ moved to Hungary for family reasons (marriage or partnership with a Hungarian citizen or family reunion). Family reasons are followed by three other motivational factors, in equal proportion $(20 \%)$, such as personal reasons (favourable geographical location and climate, self-realization, career development or search for adventure, knowledge of the citizens, culture of an unknown country), work-related tasks (company assignment) and economic reasons (low price level, low subsistence costs).

As for job-related reasons, job opportunities (they came to Hungary because of the lack of job opportunities in their home country) and as an economic motivation, the hope for better living standards (which are the most common motivational reasons for immigration to Hungary, especially for employees from countries east of Hungary) were not indicated at all by the respondents. The lack of these two motivations proves the novelty of the research. Similarly, no one came to Hungary for political and religious reasons or because of war. Some respondents indicated other reasons, such as "experience gain", "curiosity", "looks good in my CV", "escaped from my husband / wife" (1-1 people), "my decision was based on the positive example of others."

Examination of the country of origin showed that there are expressive and statistically significant differences in terms of migration motivations. People from the successor states of the Soviet Union left their country in large proportions due to family reasons, as did and immigrants from neighbouring countries and from China. It cannot be proved on the basis of the data, only a the subjective opinion that many people from former Soviet states chose the reply "family reasons", because working in Hungary for a while is considered by them as a "breakout point" since it provides them with an opportunity within the EU. Company assignment was mentioned in the highest proportion by people from the EU and certain Asian countries, while nearly one-third of the employees arriving from the Anglo-Saxon region indicated the favourable economic situation. For them, inexpensiveness played an important role when choosing the most suitable country, and in this respect, Hungary was regarded as a favourable destination. They found very favourable prices for services and local products, but in the case of department stores and shops for clothing, they felt they were on the same price level with their home country. Employees from countries outside Europe have mentioned their desire to get to know other cultures more often, than European respondents.

Almost all respondents $(90 \%)$ had prior information about Hungary before travelling here, more than half of them (57\%) had their own experience ( $41 \%$ had already been here, $16 \%$ studied here earlier), one third (33\%) knew people with own experience (a friend from home has already been here or they had Hungarian friends).

Country of origin and the existence of preliminary information have a significant correlation with each other. People from neighbouring countries or from other countries in the region, had some knowledge about Hungary because they had been here before. From among respondents who arrived to Hungary in the scope of international higher education scholarships, there are some who grew fond of Hungary, so they decided to spend a longer time here or return to us later (as employees). 16\% of the people constituting the sample had previously studied or graduated in Hungary. They are almost equally of Arabic, African and Asian origin or from the successor states of the former Soviet Union. Many of the respondents from the Middle or Far East had a friend who had already spent a long time in Hungary, had good experiences and suggested them to come here. 
The idea of finding employment abroad might be triggered by fact that the given person has foreign friends or other acquaintances who already have experience in this regard. All of that might have a stimulating effect on the decision to migrate. Nearly half of the respondents $(48 \%)$ already had Hungarian friends before moving to Hungary and almost the same amount of people $(41 \%)$ found Hungarian or other foreign friends after their arrival.

Those who did not have prior information about the country typically gained positive experiences during their time here.

In summary, it was found that respondents mostly came to Hungary for family reasons, in possession of prior information about the country. Motivations of migration and preliminary information show expressive and statistically significant differences in terms of the country of origin.

\subsection{Labour market integration}

Successful job-hunting is a precondition of labour market integration. To the question concerning how they collected information about Hungarian job opportunities (except for the respondents sent by their own company, $20 \%$ ), a surprisingly large proportion, almost half of the sample replied that they trusted their luck, which means they accidentally found the vacancy $(46 \%)$, while the remaining one third (34\%) consciously sought employment in Hungary.

In terms of job search channels, almost all of the respondents (49-49\%) found their job through advertisements or personal contacts. The remaining part $(2 \%)$ was assisted by employment agencies. Jobhunting methods have undergone a major change lately. The role of electronic communication has increased considerably and advertisements in printed media as well as institutionalized employment agencies are becoming less popular. Interpersonal relationships continue to play a major role in finding a job. Analysing the data by country of origin, there are statistically significant differences in terms of the applied channels of job-hunting. In the case of Far-Eastern ${ }^{5}$ people and respondents of Hungarian origin, personal involvement is decisive. Employees from neighbouring countries are characterized by the combined application of multiple methods.

The overwhelming majority of respondents came to Hungary in possession of a contract of employment (all of the executives) or with a promise of getting one. Those who only started looking for work once they arrived here are all employees and there is no significant difference in terms of their country of origin.

One of the determining factors of staying in Hungary is the workplace itself. In terms of geographical location, foreign employees are concentrated in the capital and in the Central Hungarian region in a much larger proportion than the domestic society; the same is true for them living in cities and regions, which provide better opportunities in terms of labour market and income conditions and for education and health care. Budapest is the most attractive target destination for potential employees, and this is where the majority of respondents (89\%) work. The others are equally distributed in different cities and county seats, and one respondent works in a village (as a teleworker).

Based on the examination of the workplace profiles of respondents, it can be stated that a larger proportion of respondents within the entire sample work in the competitive sector than in state, local government or public bodies or institutions. The vast majority of respondents were employees, as opposed to the low proportion of entrepreneurs and business owners. More than half of foreign workers

${ }^{5}$ The analysed sample did not include a considerable amount of Far Eastern small entrepreneurs, but it is expressly characteristic in their case that their employees are recruited from their own countries through personal (often family) relations. 
$(57 \%)$ work for multinational large companies situated in Hungary, followed by (16-16\%) employees working at foreign or Hungarian companies, state institutions (7\%) and some (4\%) in their own businesses.

As for their position, the largest proportion of foreigners (70\%) work as employees, and almost in the same proportion $(14 \%$ and $16 \%)$ as senior and middle managers.

As for professional activities, the proportions of employees working in the field of computer technology $(44 \%)$ and finance $(33 \%)$ are the largest ones, but there are plenty of respondents in healthcare, education, tourism, automotive industry and human relations, in a mostly equal distribution $(4.5-5 \%)$.

Regarding the nature of the activity, most respondents (83\%) carry out intellectual work and only a few $(17 \%)$ deal with physical labour. Almost all of them (91\%) continued their original profession. Those who have changed profession, make a living based on their hobbies.

Based on the country of origin, there were no significant differences among foreign employees in terms of the variables characterizing their workplace

Well-being and lifestyle of individuals and the society as a whole are controlled by the amount and structure of time spent with working. $93 \%$ of the foreign employees included in the sample work fulltime. All of the part-time employees are women from Western European countries with higher education degrees.

It is an interesting phenomenon that in terms of the amount of working hours in the home country and in Hungary, many respondents reported a slight increase: $62 \%$ used to work 6 to 8 hours, while now $63 \%$ work that much and $27 \%$ of the employees used to work $8-12$ hours $27 \%$, and $29 \%$ of them work that much currently. Proportion of employees who work less than 6 hours a day has barely changed (6$7 \%$ ), and the number of people working more than 12 hours has decreased (from 5\% to 1\%). There is a significant difference between the home country and Hungary in terms of the amount of daily working hours. Employees who work more than 10 hours a day are typically men in executive positions from Far Eastern or Eastern European countries. Employees of the public sector and of large companies work 8 hours a day.

Respondents spend an average of 2 hours a week with overtime, which is financially rewarded and highly appreciated; therefore, it is not a problem.

Two-thirds of the respondents $(68 \%)$ work 5 days a week, $11 \%$ of them reported six working days per week, while $7 \%$ of them had seven.

$10 \%$ of respondents pointed out that they spend time with their work outside their workplace; half of them carry out intellectual and half of them physical activities. According to the answers, this usually means 4-8 extra hours per week 6 .

With regard to the length of annual leave, differences occur due to the stipulations of labour laws concerning the employers. In general, Western European employees are in the most favourable position, with a summer vacation exceeding one month if the employer is also form Western Europe. The situation of Far Eastern employees is the most disadvantageous with approximately two weeks of annual holiday.

There are significant differences amongst origin countries in terms of working hours in two cases: length of annual leave and daily amount of working hours - only employees from China, Japan and former socialist countries spend more with work than the generally accepted 8 hours a day.

We also found important to evaluate the emotional status associated to work, as one of the most reliable signs of emotional integration is the self-assessment of the individual within a work environment.

\footnotetext{
${ }^{6}$ It is typical that employees from third countries work efficiently.
} 
Relationship of employees with their workplace was measured by means of a 5-scale attitude analysis, where we received the following results: wage is what foreign employees are the most satisfied with $(66 \%)$, followed by fellow employees $(62 \%)$ and then with their actual work activities $(60 \%)$. Learning (39\%) and the further career (37\%) opportunities are not considered satisfactory by more than a third of the respondents. The aggregate score of satisfaction on a five-grade scale is 3.87 , which shows that generally satisfied employees are in the majority. This is also an important element and indicator of integration. Compared to other employees, Arabic and Far Eastern respondents are significantly less satisfied with human relationships at the workplace.

There is a slight contradiction to the above, when most respondents $(87 \%)$ see a chance to build a career in Hungary and only 13\% consider their future with a negative attitude or have a neutral (not interested) attitude.

The starting point for career development and equal opportunities is whether foreign workers receive the same rights and treatment as their Hungarian colleagues and whether they are the subjects to any kind of discrimination. Most of the respondents $(75 \%)$ did not experience any kind of discrimination. The remaining one-quarter was not offended at work either, but rather in their everyday life.

The majority (81\%) are optimistic about the Hungarian labour market, and believe that the number of foreign employees and employers will increase.

Analysing the three characteristics mentioned above by the country of origin, we found that there were no statistically significant differences.

Considering the successfulness of employment in Hungary, 30\% of respondents answered that their expectations have been fully met here, $64 \%$ think that they are partially satisfied, while $6 \%$ are not satisfied at all. The most favourable assessment was given by the citizens of Western European countries working in Hungary, which is presumably justified by their higher employment position and better working and living conditions. The rate of employees who are not satisfied with their current situation in Hungary is relatively high amongst the citizens of the former Soviet Union (17\%) and Arabic people $(10 \%)$. Success in the labour market is by all means an indicator of integration. Overall, it can be concluded that the attitude of foreign employees towards work is positive.

Examination of workplace satisfaction showed significant correlation in two cases: Far and Middle Eastern employees were not contended with their human relationships, while former Soviet citizens were not satisfied with their success.

In summary, it can be established that the employees involved in the survey have found their jobs accidentally, through advertisements or personal contacts; most of them work in Budapest in the competitive sector as employees in their original profession, in ICT- and finance-related positions. Every surveyed employee works more than they did in their home country and the occasionally they even do overtime. They are generally satisfied with their workplace and their job, with their wages, colleagues and work activities. Most of them have not experienced any kind of discrimination; they are optimistic regarding the Hungarian labour market and themselves. Almost all of the respondents consider themselves fundamentally or at least partially successful.

The Chi-square test resulted in a significant correlation, which means that the labour market integration of respondents depends on the origin country of foreign employees in terms of the method of job-hunting, amount of working hours and labour market integration. On the basis of working hours, there is a significant difference amongst people from different countries in two cases: length of annual leave and generally accepted daily working hours. The same is true for workplace satisfaction in the case of the relation with fellow colleagues and success at the workplace. 


\subsection{Social integration}

As for the point of view of cognitive or cultural integration, i.e. learning the language, norms and customs, integration of foreign employees in Hungary can be considered successful. In the case of permanent employment in Hungary, a certain level of knowledge of the Hungarian language is a condition of integration. The lack of linguistic competences has a significant impact on everyday life, taking into account the shortcomings of the domestic population. A certain proportion of Arabic and African employees have studied in Hungary, so it is easier for them to adapt. Citizens of neighbouring countries have the best linguistic skills, even if they are not Hungarian native speakers. A quarter of non-Hungarian native speakers mentioned that their lack of knowledge in Hungarian caused them difficulties in the scope of their job.

For $10 \%$ of the foreign employees participating in the study (31 people), the native language is Hungarian, therefore their analysis in this regard is not necessary. For $93 \%$ of the respondents, Hungarian is not the working language, only $11 \%$ of the respondents use it regularly in the scope of their professional activities. Overall, $16 \%$ of the sample (49 people) speak and understand the language of the country, while another 7\% (22 people) are on medium level (according to their own assessment). Most people only learn the most basic gesture-like expressions that help them make themselves understood in stores and offices. The best motivation for learning the language is living in a serious relationship.

Many people are interested in Hungarian traditions (Easter customs, pig slaughter) and history, and they are familiar with the essence of religious and national holidays. Hungarian customs are also known better by foreigners who have more Hungarian friends or a Hungarian partner, or have been living in Hungary for several years.

According to our research, there is no statistically significant difference among the countries of origin of foreign employees in terms of cognitive integration; currently, conflicts related to norms and customs are very rare and they do not threaten with more severe tensions for the time being.

Concerning structural integration, results of previous studies have identified problems with equal opportunities and working/living conditions. Generally, these problems emerged in the case of immigrants with lower social class, in terms of equal access to education, training systems and healthcare services and of proper level of accommodation.

One-tenth $(10 \%)$ of the applicants already applied or are applying for Hungarian citizenship, the other respondents are not relevant in this regard. Those who already acquired Hungarian citizenship or intend to do so, explained it with family reasons. Additionally, the most attractive argument is that Hungarian citizenship is accompanied with an EU passport (1\%), which secures freedom of movement for these employees within the EU.

Analysing the above factor based on the country of origin, statistically significant difference was detectable only for neighbouring countries, which are not EU Member States and Asian countries. The Chi-square test showed a significant correlation, thus structural integration depends on the country of origin of foreign employees.

As for social integration in terms of the analysed sample, it can be established that social capital of foreign employees is considerably rich: they possess a network of contacts, which is not primarily based on their fellow immigrants.

Nearly half of the respondents (48\%) already had Hungarian friends prior to their emigration and a similar group of respondents (41\%), obtained Hungarian and other acquaintances of different nationalities after their arrival. Only $11 \%$ of the respondents do not have any Hungarian friends.

The reputation of Hungarian people according to the respondents is somewhat shaded by the insufficient English skills of the domestic population and their fear of using foreign languages. Many of 
the respondents pointed out that Hungarians actually do speak English, they are just afraid to talk. However, once the respondents managed to overcome linguistic obstacles, they usually consider Hungarians friendly and hospitable people.

According to their opinion with regard to personal relationships, although cultural and religious differences might result in problems, many mixed relationships still seem to be functional on the long term. They do not consider the listed differences the main obstacles, but parental attitude.

As for social integration, there is no statistically verifiable significant difference amongst the origin countries of foreign employees.

Identification (emotional) integration manifests itself in the subjective emotion of belonging and exclusion. Similar to the relation of employees towards their workplaces, this index is also measured by a 5 -scale attitude test for the sake of easier comparison.

An important question is how much people working abroad are able to integrate, as this may affect their identity, decisions, their accomplishments, and their everyday lives, thus their possibilities. Nearly a quarter of the respondents (23\%) are completely integrated and consider the country as their home, 51\% feel well and 10\% experience a medium level of well-being, while only $16 \%$ indicated that they were total outsiders. This is an interesting outcome, considering that no one intends to stay permanently in Hungary. Although, there are probably a high number of people within the group of uncertain respondents who actually do. Overall, $74 \%$ of the respondents gave a positive answer regarding how well they feel in Hungary. It is gratifying that most of them have good experiences.

Segregation can be experienced only sporadically, while expression of racism was barely detected in the scope of present study

Analysing the above factor by country of origin, no statistically significant difference can be observed in the case of the neighbouring states and Asian countries. The Chi-square test showed significant correlation, so identification integration depends on the country of origin of foreign employees.

In general, it can be said that social integration was mostly accomplished in the case of the analysed sample. Nearly a quarter of respondents $(23 \%)$ speak Hungarian at a certain level, $10 \%$ applied for citizenship, they are interested in traditions and customs, $89 \%$ have Hungarian friends and three quarters of them $(74 \%)$ clearly feel well in the country.

The Chi-square test showed a significant relationship, so there is a significant correlation between the country of origin of foreign employees and certain dimensions of social integration. Cognitive and social integration does not depend on the country of origin of foreign employees, while structural and identification integration does. In the case of structural integration, the matter of Hungarian citizenship showed a significant difference for non-EU member neighbouring countries and Asian countries. Identification integration was achieved less successfully in neighbouring and Asian countries.

\subsection{Opinions about people and the country}

Considerable information can be found out about ourselves, from the opinion of foreign people about the Hungarian people surrounding them.

According to our experience, foreigners employed in Hungary are reluctant (out of politeness) to talk about the problems they encountered during their employment in Hungary. However, their views and opinions have been collected in the course of the survey.

In the scope of the questionnaire, respondents had the opportunity to describe Hungarian people in 3 words. Classification of the answers formed 3 categories. A surprisingly high proportion of the sample $(62 \%)$, used only positive words for characterization, one-third $(32 \%)$ referred to the Hungarian society with mixed terms, while $6 \%$ had negative (disappointed) sentiments. 
The most common positive attributes were helpful, kind, polite, patient, friendly, open, accepting, and in some cases, the terms well-dressed and beautiful also appeared. The most frequent negative terms features were busy, rushing, drunk, rigid, lazy, untidy.

We also received a considerable amount of opposing views. The most frequent ones are the following:

- There are many unfriendly people in Hungary; they are remote, not kind with foreign people, and they also tend to avoid them.

- The friendly attitude of Hungarians was frequently highlighted as well as their helpfulness and openness.

- It was often mentioned that many Hungarians speak English, but they are afraid to use it (mostly men).

- Hungarian dishes are fatty and heavy vs. the various tastes of Hungarian cuisine provides a real gastronomic experience.

- Foreign women mentioned that they enjoy the politeness of men, who hold the door for them (!).

- As an overall opinion, generational differences were mentioned: "young people are cool, but older people are grumpy and too helpful".

One of the questions in the questionnaire asked the involved foreign employees to list Hungarian products that they came across in Hungary. In the order of frequency, these products are the following?: pálinka, Tokaji „aszú” wine, Unikum, Rubik” cube, Túró Rudi (they know it but no one likes it), goulash (they meant goulash cream), stew, floating islands, Hungarian fried bread (lángos).

\section{CONCLUSIONS, SUGGESTIONS}

Out of the wide-ranging definition of integration, the study deals with the certain key aspects of the labour market and social integration of foreigners. The purpose of present research was to become more familiar with the socio-demographic characteristics, motivations, workplace conditions and social participation of foreign employees arriving to Hungary from different countries.

The most important statements, conclusions of the study are summarized as follows:

- more than half $(58 \%)$ of foreign employees living in Hungary were inclined to leave their homeland by family or personal reasons and the largest proportion came from developed countries, with a predominance of the European Union (39\%) and neighbouring countries (13\%). Almost all respondents $(90 \%)$ had prior information about Hungary before traveling here. There is a significant difference in terms of the motivations of previous research in Hungary, whereas improved living standards and job opportunities were the leading reasons, while they were not significant at all in in the present study.

- Most of the involved employees plan to spend a medium-term (1 to 5 years) period in Hungary, but the proportion of people planning beyond 5 years is also significant. The fact that none of the respondents expressed their intention to stay here permanently refers to circular migration.

- With regard to socio-demographic characteristics and their cultural and social resources, employees arriving to Hungary have the following characteristics: they represent a nearly equal gender distribution, they are mostly single or live in a looser relationship in the capital, they are young and wellqualified.

\footnotetext{
${ }^{7}$ The first free are alcoholic beverages.
} 
- Their labour market position is characterized by a less conscious job-hunting, which indicates the shortcomings of the domestic labour market. This is confirmed by the fact that they all work in their original profession, almost half of them work in ICT-related positions. Their territorial distribution is primarily concentrated in Budapest, which reflects the geographical pattern of capital investments. Respondents consider themselves successful in terms of their position within the labour market. They are the most satisfied with their wages, their colleagues and their job-related activities, despite the fact that they all work more than in their original occupations in their home countries.

- Social inclusion is considered successful, which reflects the outstanding adaptability of foreign employees, as only a quarter $(23 \%)$ of them speaks the Hungarian language; however, their majority $(89 \%)$ have Hungarian friends. Their subjective well-being is very high, three-quarters of them feel well in Hungary.

- There were differences amongst the groups in terms of the countries of origin: large numbers of people from the successor countries of the Soviet Union, the neighbouring countries and China left their homes for family reasons; nearly one-third of the employees from the Anglo-Saxon countries were motivated by the favourable economic situation. Employees from China, Japan and the former Socialist countries work more than 8 hours per day.

- Compared to the rest of the sample, Arabic and Far Eastern employees are considerably less satisfied with their human relations at the workplace; citizens of the former Soviet Union and the Arabic employees feel less successful in their work. Citizens of the neighbouring countries and of Asian countries feel the least well in Hungary. In the case of Asian countries, this is obviously related to human relationships at the workplace. Employees from the neighbouring countries probably spend less time here as representatives of circular migration, and due to the transnational characteristics they are less likely to integrate into domestic society.

- Opposing opinions emerged about the attitude, linguistic skills and of Hungarian people and about local dishes, irrespective of the country of origin of foreign employees.

According to our research results, the process represented by the vast majority of foreign employees coming to Hungary can be referred to as circular migration, as according to the respondents they only plan to remain in the country temporarily; they intend to return to their home countries or to migrate even further.

Circular migration is a spreading practice for developed and neighbouring countries. Increasing circular migration in Hungary can be a desirable political goal both within the EU and in third countries. This includes business migration and posting. It is linked to the phenomenon of transnationalism, which is intensifying in Hungary as well. Individuals, who stay in a distant physical-social-cultural space for a long time or multiple times, might develop a bond in both directions. On the one hand, there is no need to break off their relations with the origin country; on the other hand, new ties might develop towards the environment of the receiving country.

The question of the future is how much this modern transnational status can be extended, how long can it be sustained in the course of the life of the individual. 


\section{REFERENCES}

Balcerzak, A. P. (2016), Multiple-criteria Evaluation of Quality of Human Capital in the European Union Countries, Economics and Sociology, 9(2), 11-26. doi: 10.14254/2071-789X.2016/9-2/1

Bijl, R.V., Zorlu, A., Jennissen, R.P.W., \& Blom M. (2009). The integration of migrants in the Netherlands monitored over time: Trend and cohort analyses. In: Bonifazi, C. - Okólski, M. - Schoorl, J. Simon P. (eds.) International Migration in Europe: New Trends and New Methods of Analysis, Amsterdam University Press, 199-225.

Bilan, Y., Gavurova, B., Stanisław, G., \& Tkacova, A. (2017). The Composite Coincident Indicator (CCI) for Business Cycles. Acta Polytechnica Hungarica, 14(7), 71-90.

Bodó J. (2016). Határátlépések, térbeélések. Migránsok a transznacionális térben. Iskolakultúra, 26(1), 20-30.

Bördős K., Csillag M., \& Orosz A. (2016). A bevándorlás hatása a hazai munkavállalók munkapiaci helyzetére Európában - Összefoglaló az empirikus eredményekről. In: Munkaerőpiaci Tükör 2015. MTA Közgazdaságés Regionális Tudományi Kutatóközpont Közgazdaság-tudományi Intézet, Budapest, 141-149.

Dajnoki K., \& Héder M. (2017). „Új szelek fújnak” - a HR válasza a globalizáció és a változás kihívásaira. Hadtudomány: A Magyar Hadtudományi Társaság Folyóirata, 27(E-szám) 84-93.

Dél-Alföldi Regionális Társadalomtudományi Kutatási Egyesület (2009). Biztos út a magyar munkaerőpiacra?! A bevándorlók munkaerőpiaci helyzete Magyarországon. Szeged.

Danaj, A., Lazányi, K., \& Bilan, S. (2018). Euroscepticism and populism in Hungary: The analysis of the prime minister's discourse. Journal of International Studies, 11(1), 240-247. doi:10.14254/2071-8330.2018/11-1/18

Entzinger, H., \& Biezeveld, R. (2003). Benchmarking in immigrant integration. European Research Centre on Migration and Ethnic Relations (ERCOMER), Rotterdam.

Ernest, A. T. B., \& Donald, L. N. (1972). Conceptual Frameworks for the Analysis of Race Relations: An Evaluation. Social Forces, 50(3), 333-348.

Fleischer T. (2017). A migráció és társadalmi-gazdasági összefüggései: az MTA KRTK vándorszemináriuma. Tér és Társadalom, 31(1), 147-157.

Gödri I. (2010). Bevándorlás és etnicitás - összefüggések nyomában. In: Hárs Á. -Tóth J. (eds.): Változó migráció változó környezet. MTA Etnikai-nemzeti Kisebbségkutató Intézet, Budapest, 87-124.

Gödri I. (2017). Az integráció mutatói és esélykülönbségei a Magyarországon élő bevándorlók): Bevándorlók munkaerő-piaci integrációja Magyarországon - népszámlálási helyzetkép. In Munkaerőpiaci Tükör 2015. MTA Közgazdaság- és Regionális Tudományi Kutatóközpont Közgazdaság-tudományi Intézet, Budapest, 121-134.

Gordon, M. M. (1964). Assimilation in American Life. Oxford University Press, New York.

Hárs Á. (2010). Migráció a harmadik országokból a statisztikai adatok tükrében. In: Örkény A. - Székelyi M. (eds): Az idegen Magyarország-Bevándorlók társadalmi integrációja. ELTE Eötvös Kiadó. MTA ENKI. Budapest. 1549.

Horn, D., \& Kónya, I. (2016). Bevándorlók kulturális integrációját meghatározó tényezők.: In Munkaerőpiaci Tükör 2015. MTA Közgazdaság- és Regionális Tudományi Kutatóközpont Közgazdaság-tudományi Intézet, Budapest, 149-158.

Illés, S., \& Kincses, Á. (2009). Migráció és cirkuláció. Statisz̨tikai Szemle, 87(7-8), 730-747.

Juhász, J., Makara, P., \& Makara, E. (2011). A munkaerő-piaci integráció kihívásai Magyarországon. A harmadik országbeli munkavállalók beilleszkedésének esélyei és korlátai. Kutatási záró tanulmány. Panta Rhei Társadalomkutató Bt.. Budapest 2011. június

Kovách I., Luca K., \& Szabó A. (2015). Társadalmi integráció, dezintegráció és társadalmi rétegződés." SOCIO. HU 2015.3, 63-83.

Lados G., \& Hegedűs G. (2012). A re-migráció európai és hazai lehetőségeinek értékelése a munkaerőpiac szempontjából. In: Kockázat - Konfliktus - Kihívás: A VI. Magyar Földrajzi Konferencia, a MERIEXWA 
nyitókonferencia és a Geográfus Doktoranduszok Országos Konferenciájának Tanulmánykötete. SZTE TTK Természeti Földrajzi és Geoinformatikai Tanszék, Szeged, Magyarország, 509-523.

Lazányi, K., Čepel, M., \& Bilan, S. (2017). Comparison of Trust and Social Relations among Students in Russian and Hungarian Higher Education. Economics and Sociology, 10(4), 162-174. doi:10.14254/2071-789X.2017/10-4/13

Melegh, A., Kovács, É., \& Gödri, I. (2010). „Azt hittem célt tévesztettem” - A bevándorló nők élettörténeti perspektívái, integrációja és a bevándorlókkal kapcsolatos attitűdök nyolc európai országban. KSH NKI Kutatási Jelentések 88. KSH Népességtudományi Kutatóintézet. Budapest

Oláh, J., Halasi, G., Szakály, Z., Popp, J., \& Balogh, P. (2017). The impact of international migration on the labour market-A case study from Hungary. Amfiteatru Econ., 19, 790-805.

Örkény, A., \& Székelyi, M. (2010). Hat migráns csoport összehasonlító elemzése. In: Örkény A. - Székelyi M. (eds.): Az idegen Magyarország-Bevándorlók társadalmi integrációja. ELTE Eötvös Kiadó. MTA ENKI. Budapest. 49-97.

Park, R. E. (1928). Human Migration and the Marginal Man. American Journal of Sociology, 33(6), 881-893.

Portes, A., \& Böröcz, J. (1989). Contemporary Immigration: Theoretical Perspectives on Its Determinants and Modes of Incorporation. International Migration Review, 23(3), 606-630.

Putnoki P. (2016). A kulfoildi állampolgárok magyarországi munkavállalásának fóbb sajátosságai. NGM. Kézirat.

Ruhs, M., \& Vargas-Silva, C. (2014). The labour market effects of immigration. Migration Observatory Briefing, University of Oxford. http://www.migrationobservatory.ox.ac.uk/wp-content/uploads/2016/04/BriefingLabour_Market_Effects_of_Immigration.pdf

Sík E. (2012). A migráció szociológiája1. Budapest: ELTE TáTK. 21, 7-33.

Simionescu, M., Ciuiu, D., Bilan, Y., \& Strielkowski, W. (2016). GDP and net migration in some eastern and southeastern countries of Europe. A panel data and Bayesian approach. Montenegrin Journal of Economics, 12(2), 161175

Simionescu, M., Bilan, Y., Smrčka, L., \& Vincúrová, Z. (2017a). The effects of European economic integration and the impact of brexit on the UK immigrants from the CEE countries. E+ M Ekonomie a Management, XX(1), 29-47.

Simionescu, M., Bilan, Y., \& Mentel, G. (2017b). Economic Effects of Migration from Poland to the UK. Amfiteatru Economic, 19(46), 757-770

Stone, W., \& Hughes, J. (2002). Measuring social capital: towards a standardised approach. Paper presented at the, 3(9214), 7820.

Streimikiene, D., Bilan, Y., Jasinskas, E., \& Griksaite, R. (2016). Migration Trends in Lithuania and other New EU Member States. Transformations in Business \& Economics, 15(1). 21-33.

Rausser, G., Strielkowski, W., Bilan, Y., \& Tsevukh, Y. (2018). Migrant remittances and their impact on the economic development of the Baltic States. Geographica Pannonica, 22(3), 165-175

Utasi Á. (2002). A társadalmi integráció és szolidaritás alapjai: a bizalmas kapcsolatok. Századvég- Új folyam, 24. http://www.c3.hu/scripta/szazadveg/24/utasi.htm. 2018. április 11.

Zhou, M. (1997). Segmented Assimilation: Issues, Controversies, and Recent Research on the New Second Generation. International Migration Review, 31(4), 975-1008. 